\title{
The Biochemical, Histopathological and Clinical Comparison of the Neuroprotective Effects of Subcutaneous Adalimumab and Intravenous Methylprednisolone in an Experimental Compressive Spinal Cord Trauma Model
}

\author{
Haydar CELIK ${ }^{1}$, Mete KARATAY ${ }^{1}$, Yavuz ERDEM ${ }^{1}$, Ali Erdem YILDIRIM² , Idris SERTBAS ${ }^{1}$, Eylem KARATAY ${ }^{3}$, \\ Halil KUL' ${ }^{1}$, Yahya GUVENC ${ }^{4}$, Ismet KOKSAL ${ }^{5}$, Guner MENEKSE${ }^{1}$, Fatih ALAGOZ², Huseyin Hayri KERTMEN ${ }^{6}$, \\ Muzaffer CAYDERE ${ }^{7}$ \\ ${ }^{1}$ Ankara Training and Research Hospital, Department of Neurosurgery, Ankara, Turkey \\ ${ }^{2}$ Ankara Numune Training and Research Hospital, Department of Neurosurgery, Ankara, Turkey \\ ${ }^{3}$ Istanbul Gaziosmanpasa Taksim Training and Research Hospital, Department of Gastroenterology, İstanbul, Turkey \\ ${ }^{4}$ Dr. Nafiz Korez Sincan State Hospital, Department of Neurosurgery, Ankara, Turkey \\ ${ }^{5}$ Yenimahalle Training and Research Hospital, Department of Orthopaedics and Traumatology, Ankara, Turkey \\ ${ }^{6}$ Diskapi Yildirim Beyazit Training and Research Hospital, Department of Neurosurgery, Ankara, Turkey \\ ${ }^{7}$ Ankara Training and Research Hospital, Department of Pathology, Ankara, Turkey
}

\section{ABSTRACT}

AIM: To evaluate the neuroprotective effects of adalimumab in an experimental spinal cord injury model and compare them with those of the widely-used methylprednisolone.

MATERIAL and METHODS: Forty male Wistar rats were divided into 5 as the sham, trauma, adalimumab, methylprednisolone, and adalimumab+methylprednisolone groups. Only laminectomy was performed in the sham group. Laminectomy and trauma was performed to the trauma group but no treatment was given. A single dose of $40 \mathrm{mg} / \mathrm{kg}$ subcutaneous adalimumab was administered after the laminectomy and trauma to group 3. A single dose of intravenous $30 \mathrm{mg} / \mathrm{kg}$ methylprednisolone was administered right after laminectomy and trauma to group 4. Single doses of $40 \mathrm{mg} / \mathrm{kg}$ adalimumab and $30 \mathrm{mg} / \mathrm{kg}$ methylprednisolone were administered together after laminectomy and trauma to group 5. Serum malondialdehyde (MDA), TNF-a, IL-1 $\beta$ and IL-6 levels were measured and sections were obtained for histopathological study at the end of the $7^{\text {th }}$ day.

RESULTS: MDA, TNF-a, IL-1 $\beta$ and IL-6 levels in serum were significantly decreased in the adalimumab group with clinical and histopathological improvement not less than the methylprednisolone group. The serum MDA levels were similar when the two drugs were given together or separately but there was a statistically quite significant decrease in TNF-a, IL-1 $\beta$ and IL-6 levels with concurrent use. Statistically significantly better results were obtained on histopathological evaluation with the use of both drugs together.

CONCLUSION: This study revealed that adalimumab is as effective as methylprednisolone in compressive spinal cord injury in rats. KEYWORDS: Adalimumab, Methylprednisolone, Rats, Spinal cord injuries 


\section{INTRODUCTION}

Spinal cord injury (SCl) is a significant clinical problem that can lead to persistent neurological deficits and secondary complications and decrease the quality of life. Primary mechanical damage cause by trauma to the spinal cord is followed by secondary damage with increased calcium and the release of excitatory amino acids, free oxygen radicals and many chemical substances such as TNF-a, IL-1, IL-6 and IL-8 $(20,22$, 72). Medical treatment for traumatic spinal cord injury aims to prevent secondary damage $(19,21,35,69)$.

Models such as laceration (56), impact (57), clip compression (60) and dislocation (23) have previously been used to create experimental spinal cord injury.

The neuroprotective effect of many pharmacological agents such as methylprednisolone, melatonin, erythropoietin, magnesium, mexiletine, naloxone, infliximab, clotrimazole, lamotrigine and hyperbaric oxygen in experimental spinal cord injury has been studied $(4,13,34,37-40,47,75,76,80,81)$. Among these substances, only methylprednisolone has entered clinical use (33) and it is the only agent proven to have positive effects after spinal cord injury. However, despite the beneficial effect on parenchymal damage, it has been shown not to provide a significant functional improvement (62).

TNF- $\alpha$ and pro-inflammatory cytokines such as IL-1 $\beta$ and IL-6 have been found to increase within hours after spinal cord injury and recent studies have revealed that these cytokines that increase in serum are directly related to persistent motor dysfunction and histopathological damage $(26,32,68)$.

Malondialdehyde (MDA) that has an aldehyde structure appears after breaking of the carbon bonds during lipid peroxidation. Malondialdehyde is a final product in lipid peroxidation and MDA levels are used as an indicator of the level of oxidative damage. MDA plasma and tissue levels are measured as an indicator of free radicals (55).

Adalimumab (Humira ${ }^{\mathrm{R}}$ ) is a human monoclonal TNF-a antibody drug and blocks the effects of TNF-a. It is used successfully at a dose of $40 \mathrm{mg} / \mathrm{kg}$ subcutaneously every 2 weeks in the treatment of disorders such as Crohn's disease, ulcerative colitis, psoriasis, rheumatoid arthritis, psoriatic arthritis, ankylosing spondylitis (13, 14, 42, 43, 59, 65).

This study was conducted to evaluate whether adalimumab, an agent commonly used in rheumatology and gastroenterology disorders, has neuroprotective effects in an experimental compressive spinal cord injury model by assessment of histopathological changes in the traumatized tissue; serum MDA, TNF-a, IL-1 $\beta$ and IL-6 measurements; and clinical use of the inclined plane test and modified Tarlov's Grading Scale. We then compared the results with those of methylprednisolone, another commonly used agent. This is the first study to investigate the neuroprotective effects of adalimumab in experimental spinal cord injury.

\section{MATERIAL and METHODS}

\section{Experimental Groups}

Approval was obtained from the Ministry of Health Ankara Training and Research Hospital Ethical Committee for the study. The surgical procedures of the study were performed at the Ministry of Health Ankara Hospital Experimental Animal Laboratory. A total of 40 adult male Albino Wistar rats (8 rats in each of the 5 groups) weighing between 250 and $300 \mathrm{~g}$ were used in this study. The rats were selected randomly and divided into 5 groups as the sham, trauma, adalimumab, methylprednisolone and adalimumab+methylprednisolone groups as follows:

- Group 1: Only laminectomy was performed to the 8 rats in the sham group; trauma (spinal cord injury, sci) was not performed and no treatment was used.

- Group 2: Laminectomy and acute trauma (sci) were performed to the 8 rats in the trauma group; no treatment was given.

- Group 3: A single dose of subcutaneous $40 \mathrm{mg} / \mathrm{kg}$ adalimumab (Humira, Abbott Laboratories, North Chicago, IL, USA) was administered right after laminectomy and acute trauma (sci) to the 8 rats.

- Group 4: A single dose of $30 \mathrm{mg} / \mathrm{kg}$ intravenous methylprednisolone (Prednol, Mustafa Nevzat, Turkey) was administered right after laminectomy and acute trauma (sci) to the 8 rats.

- Group 5: Single doses of $40 \mathrm{mg} / \mathrm{kg}$ adalimumab and intravenous $30 \mathrm{mg} / \mathrm{kg}$ methylprednisolone were administered together right after laminectomy and acute trauma (sci) to the 8 rats.

\section{Anesthesia and Surgical Procedure}

The animals were kept at $18-21^{\circ} \mathrm{C}$ under constant laboratory conditions consistent with a biorhythm with a 12-hour lightdark cycle and were allowed free access to food and water. General anesthesia was ensured with an intramuscular injection of $5 \mathrm{mg} / \mathrm{kg}$ ketamine hydrochloride (Ketalar, Pfizer, İstanbul, Turkey) and $70 \mathrm{mg} / \mathrm{kg}$ xylazine (Rompun, Bayer, İstanbul, Turkey). Rats under anesthesia were secured in the prone position using all four extremities. Intramuscular cefotaxime (Bilim Pharmaceuticals, Beyoglu, Istanbul) was administered at a dose of $40 \mathrm{mg} / \mathrm{kg}$ prophylactically 30 minutes before the surgical procedure. The entire dorsal midline was shaved and surface sterilization was provided with polivinylpyrolidone iodine $($ Polyod $\AA$, 10\% solution, Drogsan İlaç Sanayi, Ankara, Turkey). The midline incision was performed with aseptic technique along the T5 to T12 spinal processes. The paravertebral muscles were dissected from the T7 to the T10 vertebrae. Once the vertebral column between T7 and T10 was exposed, total laminectomy was performed with a surgical microclamp. The dura was left intact. An aneurysm clip (Yaşargil, FE 721, Aesculap, Germany) with a closure strength $70 \mathrm{~g}$ was used for 1 minute to create spinal cord injury in all groups except group 1 (Figure 1). Paraplegia was observed in all rats in groups 2-5 where trauma was created. 
Only laminectomy was performed for the 8 rats in group 1 . The 8 rats in group 2 underwent laminectomy and trauma (sci) but no treatment was administered. The 8 rats in group 3 were administered a single dose of $40 \mathrm{mg} / \mathrm{kg}$ adalimumab right after laminectomy and trauma (sci). The 8 rats in group 4 were administered a single dose of $30 \mathrm{mg} / \mathrm{kg}$ methylprednisolone right after laminectomy and trauma (sci). The 8 rats in group 5 were administered single doses of $40 \mathrm{mg} / \mathrm{kg}$ adalimumab and intravenous $30 \mathrm{mg} / \mathrm{kg}$ methylprednisolone. The incisions were closed with primary sutures after the surgery. The animals were provided food and water and kept in a temperature-controlled room until the end of the experimental protocol. Motor strength and the inclined plane test were evaluated in all rats at 24 hours and 3, 5 and 7 days after trauma. Sedation was provided with intramuscular ketamine and xylazine at the end of the $7^{\text {th }}$ day and blood samples were obtained to determine plasma MDA, IL-1 $\beta, I L-6$ and TNF-a levels before the rats were sacrificed with the administration of pentobarbital at an excessive dose. The spinal cords were excised at a length of $2 \mathrm{~cm}$ at the area of injury ( $1 \mathrm{~cm}$ rostral and $1 \mathrm{~cm}$ caudal) and sections were obtained for histopathological study.

\section{Biochemical Analysis}

The plasma MDA level of the rats in the control and trauma groups was studied according to the method described by Draper and Hadley (16). Plasma levels were measured in $\mathrm{nmol} / \mathrm{ml}$ with this method based on the measurement of the intensity of the mixture formed by the interaction of MDA, which is a lipid peroxidation product, and thiobarbituric acid with a spectrophotometer (Beckman Coulter) at a wavelength of $532 \mathrm{~nm}$.

Serum concentrations of the inflammatory mediators (IL-1 $\beta$, IL-6 and TNF-a) were measured in pictograms per milliliter $(\mathrm{pg} / \mathrm{mL})$ with the Bio Elisa Reader Elx800 (BioTek Instruments Inc., Winooski, VT) ELISA (enzyme-linked immunosorbent assay) analysis (using ELISA kits (Bender MedSystems Gmbh, Vienna, Austria) designed for rats).

\section{Histopathological Analysis}

Anesthesia was ensured with the injection of a ketamine and xylazine solution at the end of the seventh day and samples were obtained for serum MDA, IL-1 $\beta, I L-6$ and TNF- a measurements. The skin sutures were then removed and the paravertebral muscles pulled aside. A cord segment $2 \mathrm{~cm}$ in length was separated $1 \mathrm{~cm}$ rostral and $1 \mathrm{~cm}$ caudal from the trauma region of the spinal cord. All samples were fixed in $10 \%$ neutral buffered formalin, embedded in paraffin, and $5 \mu \mathrm{m}$ thick profiles obtained with a microtome. The tissue sections were stained with H\&E and evaluated under an Olympus BX51 light microscope using a semi-quantitative grading scale (Table I) (80).

A total score between 0 and 12 was calculated according to the semi-quantitative grading scale as follows:

0 to 3 points (Grade 1 ) indicated minimal bleeding and necrosis.

4 to 7 points (Grade 2) indicated moderate tissue damage.

8 to 12 points (Grade 3 ) indicated severe tissue damage.

\section{Inclined Plane Test}

The functional improvement of the rats was evaluated using the inclined area (inclined plane) method identified by Rivlin and Tator that is commonly used in experimental acute spinal

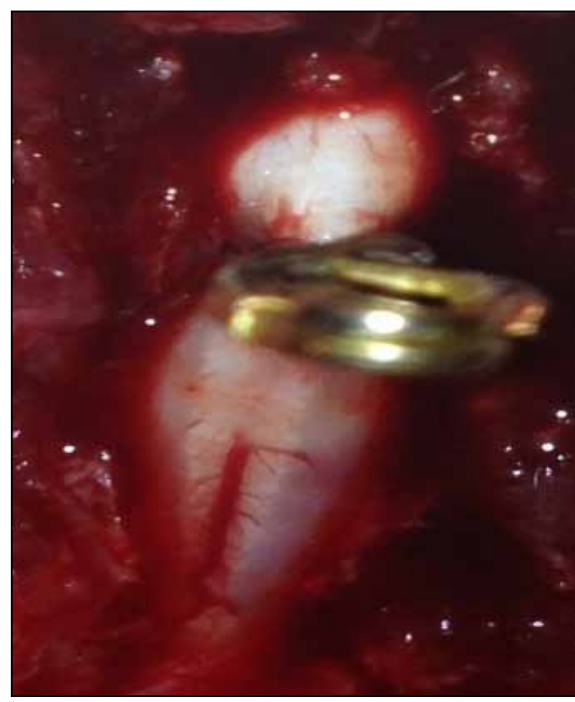

Figure 1: The creation of compression trauma with the Yaşargil clip is shown.

Table I: Semi-Quantitative Grading Method

\begin{tabular}{ll}
\hline Histopathological examination & Points \\
\hline Edema & \\
\hline No edematous tissue & 0 \\
\hline Minimal edema & 1 \\
\hline Moderate edema & 2 \\
\hline Heavy edema & 3 \\
\hline
\end{tabular}

Tissue necrosis

\begin{tabular}{cl}
\hline No necrotic tissue & 0 \\
\hline $1 \%-10 \%$ necrosis & 1 \\
\hline $1 \%-25 \%$ necrosis & 2 \\
\hline Necrosis $>25 \%$ & 3 \\
\hline
\end{tabular}

\section{Bleeding}

\begin{tabular}{ll}
\hline No bleeding & 0 \\
\hline Minimal bleeding & 1 \\
\hline Moderate bleeding & 2 \\
\hline Severe bleeding & 3 \\
\hline
\end{tabular}

\section{Inflammation}

\begin{tabular}{ll}
\hline No inflammatory cells & 0 \\
\hline Few and focal cells & 1 \\
\hline More cells & 2 \\
\hline Abscess formation & 3 \\
\hline
\end{tabular}


cord injuries (61). The rat was placed on a smooth-surfaced plane placed parallel to the floor. The plane was then lifted from the unfixed side and the inclination was increased. The highest angle the animal could stand on the plane for 5 seconds without falling was accepted as the inclined plane angle. The inclined plane test was applied to the rats in all groups 24 hours and 3, 5 and 7 days after the surgical procedure.

\section{Clinical Motor Examination}

Open-field behavior was assessed and scored with the Modified Tarlov's Grading Scale (1: No movement, 2: minimal hindlimb movement but unable to stand, 3 : able to stand but unable to walk, 4: able to walk with mild spasticity or incoordination of the hindlimb, 5: normal motor function) as proposed by Cheng et al. (10). The mean of the evaluator scores was accepted as the final score of the rat.

\section{Statistical Analysis}

The SPSS 15 (version 15.0; SPSS Inc., Evanston, IL, USA) program was used to evaluate the findings of our study. The Mann-Whitney $U$ test was used for the evaluation of nonparametric numerical data, and the Pearson Chi-square test for the comparison of categorical data. All data are presented as mean \pm standard error (SE). A p value less than 0.05 was accepted as statistically significant.

\section{RESULTS}

\section{Biochemical Results}

Plasma levels of the groups are presented in Table II. There was a statistically significant increase in all 4 mediators (MDA, IL-1 $\beta$, IL-6 and TNF-a) in the trauma group (group 2) compared to the sham group $(p<0.05)$. There was a statistically significant decrease in all 4 mediators between the trauma group and the treated groups 3,4 and $5(p<0.05)$. The concurrent administration of adalimumab and methylprednisolone created no statistically significant decrease in the MDA level compared to separate administration while the decrease in the IL-1 $1 \beta$, IL- 6 and TNF- $\alpha$ levels was quite significant $(p<$ 0.05).

\section{Histopathological Results}

Histopathological results have been presented in Table III and the histopathological photographs of the groups are shown in Figures 2-6.

According to the semi-quantitative grading system, the total score was 9.26 (grade 3 ) in the trauma group, 5.75 (grade 2) in the adalimumab group, 5.51 (grade 2) in the methylprednisolone group and 4.76 (grade 2) in the adalimumab + methylprednisolone group. Statistical analysis with Pearson's Chi-square test showed that the best results were in group 5 where both drugs had been administered together when compared to the trauma group (group 2) although not statistically significant $(p=0.076)$. There was no difference regarding edema and bleeding between the trauma group (group 2) and the treatment groups 3, 4 and 4. However, there was a statistically significant difference between necrosis and inflammation the trauma group (group 2 ) and the treatment groups 3,4 and $5(p<0.05)$.

\section{Evaluation of the Inclined Plane Test}

Inclined plane levels are presented in Table IV. There was a statistically significant decrease in the sham group compared to the trauma group $(p<0.05)$. There was a statistically significant increase in treatment groups 3,4 and 5 compared to the trauma group $(p<0.05)$. There was no difference between administering the two drugs together compared to

Table II: Biochemical Values of the Groups in Plasma. Values are Expressed as a Mean \pm SD

\begin{tabular}{lcccc}
\hline Group & MDA & IL-1 $\beta$ & IL6 & TNF- $\mathbf{a}$ \\
\hline 1 (sham) & $3.237 \pm 0.948$ & $46.000 \pm 8.035$ & $0.406 \pm 0.071$ & $20.625 \pm 6.022$ \\
\hline 2 (trauma) & $9.237 \pm 0.892$ & $106.250 \pm 11.597$ & $1.010 \pm 0.101$ & $88.875 \pm 11.933$ \\
\hline 3 (adalimumab) & $5.012 \pm 1.163$ & $66.250 \pm 5.522$ & $0.650 \pm 0.036$ & $42.500 \pm 3.338$ \\
\hline 4 (methylprednisolone) & $5.062 \pm 1.198$ & $67.000 \pm 2.878$ & $0.686 \pm 0.043$ & $46.000 \pm 4.869$ \\
\hline 5 (adalimumab+ methylprednisolone) & $4.187 \pm 0.888$ & $59.625 \pm 3.248$ & $0.588 \pm 0.043$ & $39.250 \pm 1.669$ \\
\hline
\end{tabular}

Table III: The Histopathological Evaluation Scores of the Groups. Values are Expressed as a Mean \pm SD

\begin{tabular}{lcccc}
\hline Group & Edema & Bleeding & Necrosis & Inflammation \\
\hline 1 (sham) & 0.00 & 0.00 & 0.00 & 0.00 \\
\hline 2 (trauma) & $2.00 \pm 0.926$ & $2.13 \pm 0.641$ & $2.50 \pm 0.535$ & $2.63 \pm 0.518$ \\
\hline 3 (adalimumab) & $1.50 \pm 0.756$ & $1.75 \pm 0.707$ & $1.25 \pm 0.707$ & $1.25 \pm 0.707$ \\
\hline 4 (methylprednisolone) & $1.38 \pm 0.744$ & $1.63 \pm 0.744$ & $1.25 \pm 0.886$ & $1.25 \pm 0.707$ \\
\hline 5 (adalimumab + methylprednisolone) & $1.38 \pm 0.744$ & $1.50 \pm 0.756$ & $1.13 \pm 0.835$ & $0.75 \pm 0.707$ \\
\hline
\end{tabular}


separately at 24 hours but there was a statistically significant difference on day 3,5 and $7(p<0.05)$.

\section{Evaluation of Motor Strength}

Motor strength evaluation results are presented in Table V. There was a statistically significant decrease in the trauma group compared to the sham group $(p<0.05)$. The $7^{\text {th }}$ day motor evaluation results in the trauma group administered adalimumab (group 3) was close to statistical significance ( $7^{\text {th }}$ day, $\left.p=0.053\right)$. The administration of both drugs together showed a statistically significant difference on the $5^{\text {th }}$ and $7^{\text {th }}$ days compared to separate administration $(p<0.05)$.
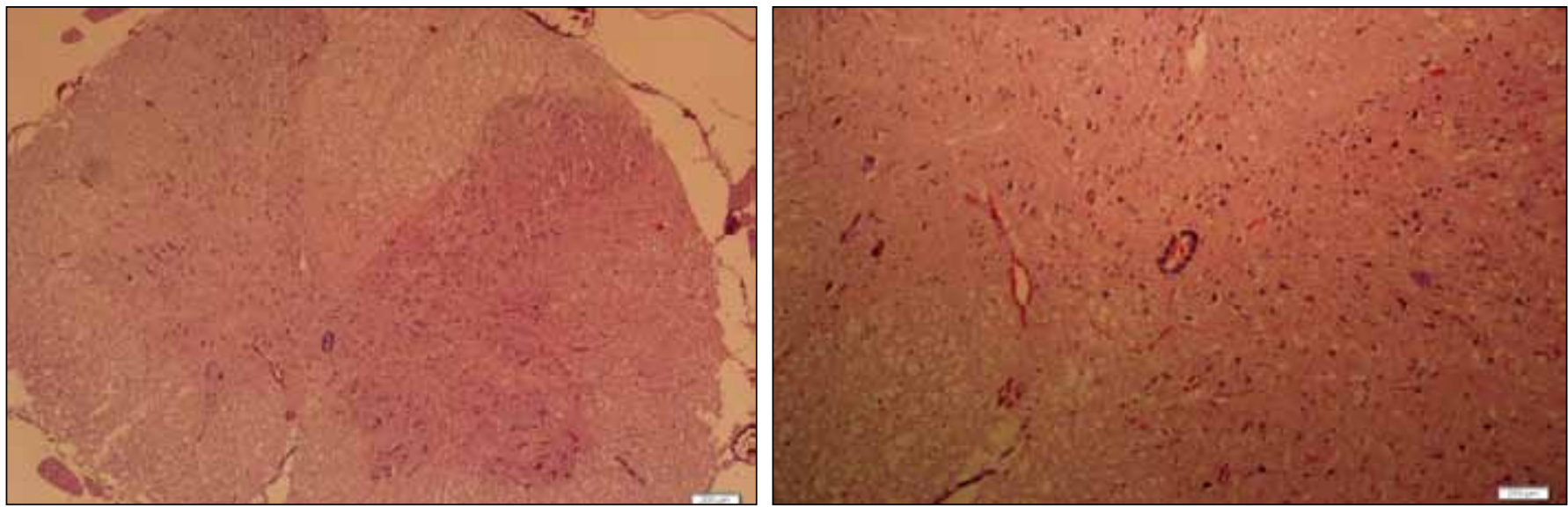

Figure 2: Sham group. Normal histomorphology in the spinal cord (Left, hematoxylin-eosin (H\&E) x40; Right, (H\&E) x100).
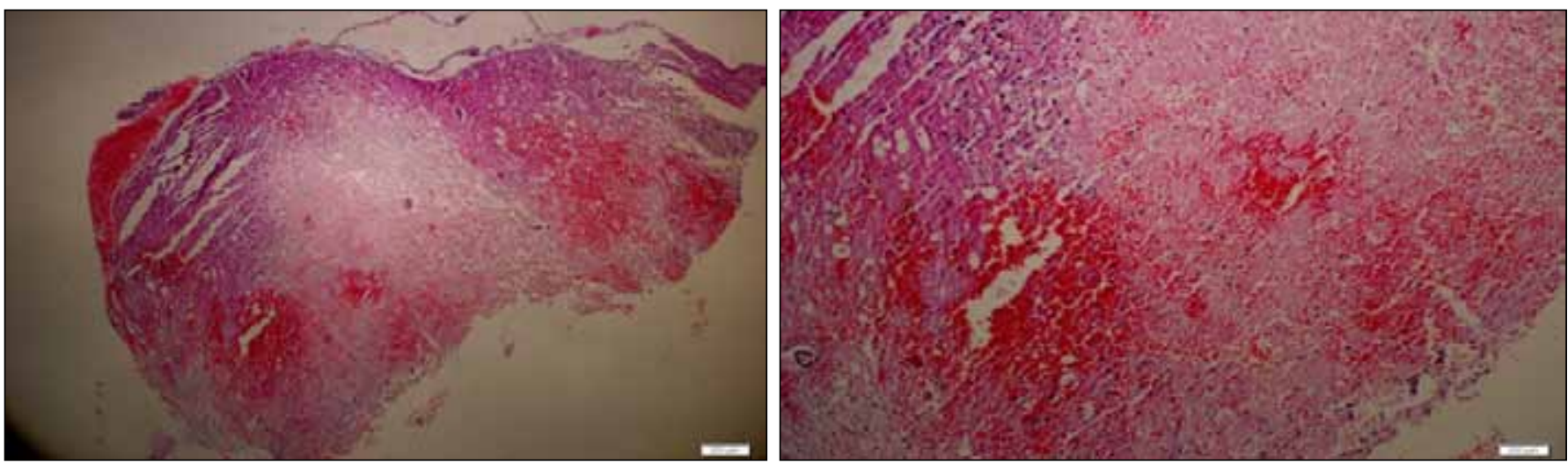

Figure 3: Trauma group (untreated group).Severe hemorrhage and necrosis in the spinal cord (Left, (H\&E) x40; Right, (H\&E) x100) (Grade 3).
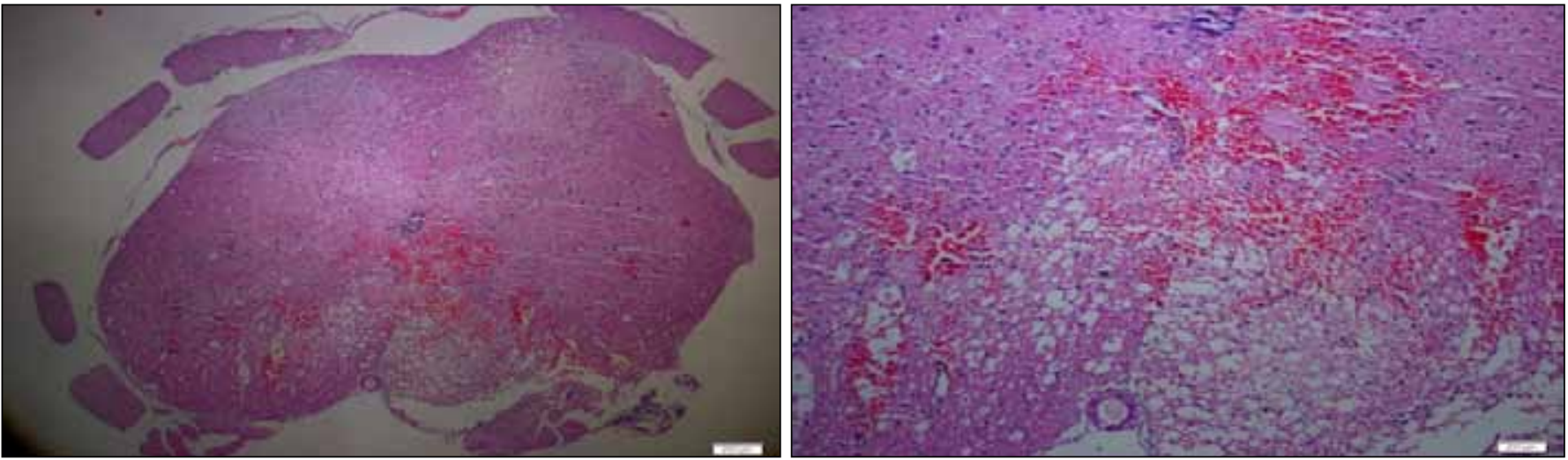

Figure 4: Adalimumab group. Mild hemorrhage in the spinal cord (Left, (H\&E) x40; Right, (H\&E) x100) (Grade 2). 
Table IV: Inclined Plane Results for the 5 Groups. Values are Expressed as a Mean \pm SD

\begin{tabular}{lcccc}
\hline Group & 24 hours & Day 3 & Day 5 & Day 7 \\
\hline 1 (sham) & $64.37 \pm 1.408$ & $64.25 \pm 1.164$ & $64.25 \pm 1.281$ & $64.37 \pm 1.187$ \\
\hline 2 (trauma) & $34.25 \pm 1.669$ & $34.50 \pm 2.070$ & $35.00 \pm 2.725$ & $34.125 \pm 2.587$ \\
\hline 3 (adalimumab) & $42.50 \pm 2.070$ & $44.50 \pm 1.603$ & $47.50 \pm 2.203$ & $49.50 \pm 2.203$ \\
\hline 4 (methylprednisolone) & $42.00 \pm 2.726$ & $43.00 \pm 2.203$ & $46.00 \pm 2.000$ & $47.50 \pm 2.070$ \\
\hline 5 (adalimumab+ methylprednisolone) & $44.50 \pm 1.852$ & $47.00 \pm 2.267$ & $50.50 \pm 2.203$ & $54.00 \pm 2.267$ \\
\hline
\end{tabular}

Table V: Motor Scores in the 5 Groups. Values are Expressed as a Mean \pm SD

\begin{tabular}{lcccc}
\hline Group & 24 hours & Day 3 & Day 5 & Day 7 \\
\hline 1 (sham) & $5.00 \pm 0.00$ & $5.00 \pm 0.00$ & $5.00 \pm 0.00$ & $5.00 \pm 0.00$ \\
\hline 2 (trauma) & $1.25 \pm 0.463$ & $1.25 \pm 0.463$ & $1.25 \pm 0.463$ & $1.25 \pm 0.463$ \\
\hline 3 (adalimumab) & $1.38 \pm+0.518$ & $1.38 \pm 0.518$ & $1.63 \pm 0.518$ & $1.75 \pm 0.463$ \\
\hline 4 (methylprednisolone) & $1.38 \pm 0.518$ & $1.38 \pm 0.518$ & $1.50 \pm 0.535$ & $1.50 \pm 0.535$ \\
\hline 5 (adalimumab+ methylprednisolone) & $1.63 \pm 0.518$ & $1.75 \pm 0.707$ & $1.88 \pm 0.641$ & $2.13 \pm 0.641$ \\
\hline
\end{tabular}

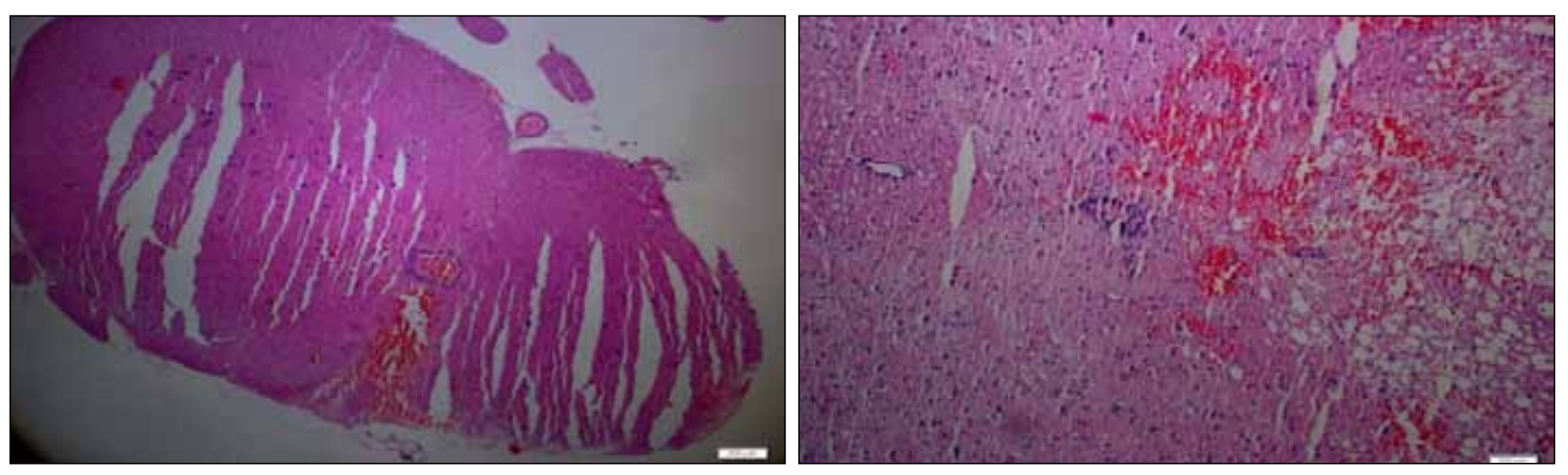

Figure 5: Methylprednisolone group. Mild to moderate hemorrhage and some necrosis foci in the spinal cord (Left, (H\&E) $\mathrm{x} 40$; Right, (H\&E) x200) (Grade 2).
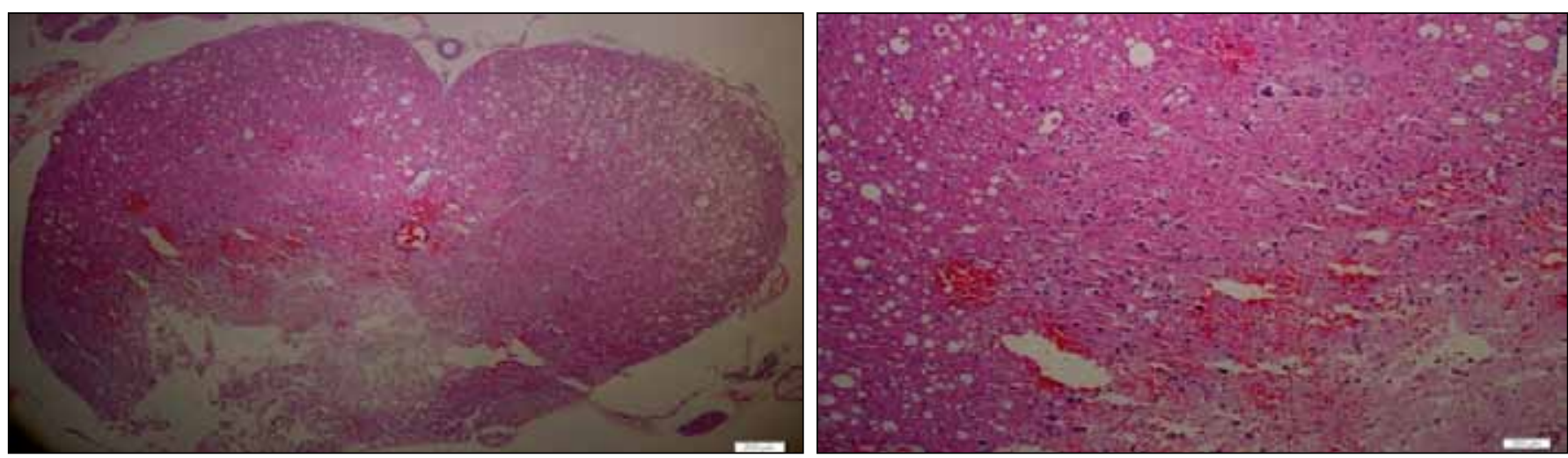

Figure 6: Adalimumab and Methylprednisolone group. Minimal bleeding and minimal necrosis are seen in the spinal cord section. (Left, (H\&E) x40; Right, (H\&E) x200) (Grade 2). 


\section{DISCUSSION}

The primary injury in traumatic spinal cord injuries occurs at the time of trauma (72). Bleeding, edema, axonal and neuronal necrosis and cyst formation are seen together with pathological changes such as demyelination followed by infarction after acute injury $(1,35,72)$. There is as yet no specific pharmacological treatment to prevent primary spinal cord injury. Secondary spinal cord injury is the damage occurring within hours as a result of the metabolic, biochemical and pathophysiological factors due to the primary injury $(3,18,70)$. The factors that play a role in this progressive process have not been fully elucidated. In addition to excessive release of glutamate and aspartate, intracellular calcium accumulation, activation of the arachidonic acid cascade, activation of various proteases such as caspase phospholipase-endonuclease, and induction of the peroxidation of lipids of free radical origin $(30,41,78)$, sympathetic stimulation also contributes to secondary injury mechanisms through altered blood flow and changes in microvascular permeability although the mechanism is not fully understood $(4,14)$. Rapid neutrophil migration occurs to the injured region (9). The antioxidant and oxidant systems of the organism are normally in balance. When this balance is disturbed in favor of the oxidants, leucocytes produce inflammatory mediators (bradykinin, prostaglandin, leukotriene, platelet activating factor, serotonin, the adhesion molecule P-selectin, interleukin 1 1 , IL-6 and TNF- $\alpha$ ) and free oxygen radicals $(17,73)$. The central nervous system is mostly formed of lipids and the lipid peroxidation caused by free radicals can therefore cause serious damage here (64).

TNF-a is a cytokine with pro-inflammatory and immunoregulatory characteristics. The biological half-life of TNF-a is short and its level increases in the damaged cord area within the first few hours after spinal cord trauma, in the cerebrospinal fluid (CSF) after a couple of hours, and in the serum later with the level proportional to the severity of the damage $(5,78,79)$. Yuji and Kenji developed an experimental spinal cord trauma in rats and found TNF-a to increase and reach peak values in damaged tissue 4 hours later (82). TNF-a facilitated the initiation of a local immune reaction in nerves. This cytokine causes damage in the blood-nerve barrier and has a cytotoxic effect on the vascular endothelium and increases vascular permeability $(58,66)$. It therefore facilitates the passage of factors in the circulation such as immunoglobulins, cytokines and complements to the nerve tissue $(31,74)$. TNF-a shows a myelinotoxic effect by stimulating the local macrophages as it increases the release of inflammatory mediators and phagocytosis (44). IL-6 is the most effective stimulant of acute phase reactant synthesis in the liver. Mononuclear phagocytic cells, fibroblasts, endothelial cells, B and T lymphocytes, glial cells and bone marrow stroma cells are the sources of IL-6 that plays an important role in defense mechanisms by regulating the immune response, acute phase reactions and hematopoesis. Its release starts after TNF-a and IL- 1 a following trauma. It is found in the serum a couple of hours after trauma and stays in the circulation for a few days. TNF- $a$, IL- 6 and IL $1 \beta$ levels increase proportionally to the severity of the trauma after spinal cord injuries and this increase is related to histopathologi- cal damage such as cell death and inflammation $(36,69,78$, $79)$ as well as persistent motor dysfunction $(26,32,68)$.

Many investigators are working on developing different methods to simulate acute spinal cord injury pathophysiological mechanisms in order to correct neurological functions (72). Although many pharmacological agents have been tried for such injuries, none of them has been accepted for clinical use except methylprednisolone $(12,50)$. The mechanism of the neuroprotective effect of methylprednisolone is not known but it decreases lipid peroxidation, stabilizes intracellular and extracellular $\mathrm{Ca}^{++}$flow, increases spinal blood flow, decreases $\mathrm{Na}^{+}$and water retention of the lesion and prevents $\mathrm{K}^{+}$loss when given at an early stage in spinal cord injury. It has anti-edema and antioxidant effects $(6,27-29,52,70,83)$. It is known to decrease TNF- $a$ and IL-6 production (24). The NASCIS-II study showed that the dose-dependent antioxidant effect of methylprednisolone was maximum at a dose of $30 \mathrm{mg} / \mathrm{kg}$ while the harmful effects started after $60 \mathrm{mg} / \mathrm{kg}$; methylprednisolone given within the first 8 hours provided better neurological recovery in long-term follow-up (7). The NASCIS-III study aimed to determine how long methylprednisolone treatment should last and reported that treatment lasting more than 24 hours did not make a neurological change in patients who were started methylprednisolone within the first 3 hours after the injury while prolongation of methylprednisolone treatment that was started within 3-8 hours after the injury to 48 hours increased neurological recovery (8). However, many clinics are now abandoning the use of methylprednisolone in clinical spinal cord trauma. Plasma MDA levels increase in spinal cord injury $(11,45,48,49)$. A significant decrease in MDA levels has been shown to be present following the administration of methylprednisolone for the treatment of spinal cord compression injury (46).

Adalimumab (Humira ${ }^{\circledR}$ ) is a human monoclonal TNF-a antibody drug and blocks the effects of TNF-a. It is used successfully for the treatment of disorders such as Crohn's disease, ulcerative colitis, psoriasis, rheumatoid arthritis, psoriatic arthritis, ankylosing spondylitis. Successful results can be obtained with $40 \mathrm{mg} / \mathrm{kg}$ subcutaneously every 2 weeks. It specifically blocks the interaction of the p55 and p75 TNF receptor surface and TNF-a (25). Side effects include development of motor neuropathy characterized by transmission block $(51,53,54$, $67)$, local injection site reactions, and secondary infective activations including fungal infections and tuberculosis. It can rarely cause lymphoma, lupus-like syndrome, cytopenia, mononeuritis multiplex, acute phrenic neuropathy and multiple sclerosis. It should be used carefully in patients at risk as it can cause pancytopenia and increase certain liver transaminases $(2,51,63)$. Infliximab is another anti-TNF agent that has been tried in a spinal cord injury model and shown to have neuroprotective effects (47).

\section{CONCLUSION}

Adalimumab is as effective as methylprednisolone for clinical, histopathological and biochemical recovery in compressive spinal cord injuries in rats. A positive synergistic effect was seen in the late stage (day 5 and 7 in particular) of trauma 
regarding the levels of biochemical markers (except MDA), inclined plane levels and motor strength evaluations with the administration of these two drugs together and the difference in histopathological results was close to significance. However, further studies with different and repeated doses of adalimumab in addition to functional, behavioral and biochemical analyses are needed.

\section{REFERENCES}

1. Agrawal SK, Nashmi R, Fehlings MG: Role of L-and N-type calcium channels in the pathophysiology of traumatic spinal cord white matter injury. Neuroscience 99:179-188, 2000

2. Alexopoulou A, Koskinas J, Soultati A, Katsaounis P, Kilidireas $\mathrm{K}$, Papageorgiou C, Antoniou C, Katsambas A, Archimandritis A: Acute bilateral phrenic neuropathy following treatment with adalimumab. Clin Rheumatol 28(11):1337-1340, 2009

3. Anderson DK, Means ED, Waters TR, Green ES : Microvascular perfusion and metabolism in injured spinal cord after methylprednisolone treatment. J Neurosurg 56:106-113, 1982

4. Aslan A, Cemek M, Eser O, Altunbaş K, Buyukokuroglu ME, Cosar M, Baş O, Ela Y, Fidan H: Does dexmedetomidine reduce secondary damage after spinal cord injury? An experimental study. Eur Spine J 8:336-344, 2009

5. Bartholdi D, Schwab ME: Expression of pro-inflammatory cytokine and chemokine mRNA upon experimental spinal cord injury in mouse: An in situ hybridization study. Eur $\mathrm{J}$ Neurosci 9(7):1422-1438,1997

6. Bracken MB: Steroids for acute spinal cord injury. Cochrane Database Syst Rev (3):CD001046,2002

7. Bracken MB, Holford TR: Effects of timing of methylprednisolone or naloxone administration on recovery of segmental and long-tract neurological function in NASCIS 2. J Neurosurg 79(4):500-507, 1993

8. Bracken MB, Shepard MJ, Holford TR, Leo-Summers L, Aldrich EF, Fazl M, Fehlings MG, Herr DL, Hitchon PW, Marshall LF, Nockels RP, Pascale V, Perot PL Jr, Piepmeier JM, Sonntag VKH, Wagner F, Wilberger JE, Winn HR, Young W: Methylprednisolone or tirilazad mesylate administration after acute cord injury: 1-year follow-up-results of the third national acute cord injury study randomized controlled trial. $J$ Neurosurg 89: 699-706, 1998

9. Can M, Gul S, Bektas S, Hancı V, Acıkgoz S: Effects of dexmedetomidine or methylprednisolone on inflammatory responses in spinal cord injury. Acta Anaesthesiol Scand 53(8):1068-1072, 2009

10. Cheng H, Cao Y, Olson L: Spinal cord repair in adult paraplegic rats: Partial restoration of hind limb function. Science 273(5274):510-513, 1996

11. Christie SD, Comeau B, Myers T, Sadi D, Purdy M, Mendez I: Duration of lipid peroxidation after acute spinal cord injury in rats and the effect of methylprednisolone. Neurosurg Focus 25(5):E5, 2008

12. Chvatal SA, Kim YT, Bratt-Leal AM, Lee $H$, Bellamkonda RV: Spatial distribution and acute anti-inflammatory effects of methylprednisolone after sustained local delivery to the contused spinal cord. Biomaterials 29(12):1967-1975, 2008
13. Colombel JF, Sandborn WJ, Panaccione R, Robinson AM, Lau W, Li J, Cardoso AT: Adalimumab safety in global clinical trials of patients with Crohn's disease. Inflamm Bowel Dis 15(9):1308-1319, 2009

14. Cosar M, Eser O, Fidan H, Sahin O, Buyukbas S, Ela Y, Yagmurca M, Ozen OA: The neuroprotective effect of dexmedetomidine in hippocampus of rabbits after subarachnoid hemorrhage. Surg Neurol 71(1):54-59, 2009

15. Cre'ange A, Be'lec L, Clair B, Raphael JC, Gherardi RK: Circulating tumor necrosis factor (TNF)- $a$ and soluble TNF-a receptors in patients with Guillain-Barre syndrome. J Neuroimmunol 68: 95-99, 1996

16. Draper $\mathrm{HH}$, Hadley $\mathrm{M}$ : Malondialdehyde determination as index of lipid peroxidation. Methods Enzymol 186:421-431, 1990

17. Dumont RJ, Okonkwo DO, Verma S, Hurlbert J: Acute spinal cord injury, Part I: Pathophysiologic Mechanisms. Clin Neuropharmacology 24 (5): 254-264,2001

18. Emery E, Aldana P, Bunge MB, Puckett W, Srinivasan A, Keane RW, Bethea J, Levi AD: Apoptosis after traumatic human spinal cord injury. J Neurosurg 89:911-920,1998

19. Erman T, Tuna M, İldan F, Göçer Ai, Vezir M, Boyar B: Spinal kord travmasının fizyopatolojisi ve medikal tedavi prensipleri. Arşiv 11:270-273, 2002 (in Turkish)

20. Faden Al, Simon RP: A potential role for excitotoxins in the pathophysiology of spinal cord injury. Ann Neurol 23(6):623626, 1988

21. Fehlings MG, Sekhon LH, Tator C: The role and timing of decompression in acute spinal cord injury. Spine 26: 101-110, 2001

22. Fehlings $M G$, Tator $\mathrm{CH}$, Linden RD: The relationships among the severity of spinal cord injury, motor and somatosensory evoked potentials and spinal cord blood flow. Electroencephalogr Clin Neurophysiol 74(4):241-259, 1989

23. Fiford RJ, Bilston LE, Waite P, Lu J: A vertebral dislocation model of spinal cord injury in rats. J Neurotrauma 21(4):451458, 2004

24. Fu ES, Saporta S: Methylprednisolone inhibits production of interleukin-1beta and interleukin- 6 in the spinal cord following compression injury in rats. J Neurosurg Anesthesiol 17:82-85, 2005

25. Gartlehner G, Thieda P, Morgan LC, Thaler K, Hansen RA, Jonas B: Drug Class Review: Targeted Immune Modulators: Final Report Update 2. Portland (OR): Oregon Health \& Science University, 2009

26. Gong G, Yuan LB, Hu L,Wu W, Yin L, Hou JL, Liu YH, Zhou LS: Glycyrrhizin attenuates rat ischemic spinal cord injury by suppressing inflammatory cytokines and HMGB1. Acta Pharmacol Sin 33: 11-18, 2012

27. Hall ED: Inhibition of lipid peroxidation in CNS trauma. J Neurotrauma 8 (Suppl 1):S31-40 discussion S1, 1991

28. Hall ED: Lipid antioxidants in acute central nervous system injury. Ann Emerg Med 22(6):1022-1027, 1993

29. Hall ED: The neuroprotective pharmacology of methylprednisolone. J Neurosurg 76(1):13-22, 1992

30. Hall ED, Wolf DL: A pharmacological analysis of the pathophysiological mechanisms of posttraumatic spinal cord ischhemia. J Neurosurg 64: 951-961, 1986 
31. Hartung HP, Jung S, Stoll, Zielasek J, Schmidt B, Archelos JJ, Toyka KV: The role of inflammatory mediators in demyelinating disorders of the CNS and PNS. J Neuroimmunol 40:197-210, 1992

32. Hasturk A, Atalay B, Caliskaneller T, Ozdemir O, Oruckaptan $\mathrm{H}$, Altinors $\mathrm{N}$ : Analysis of serum pro-inflammatory cytokine levels after rat spinal cord ischemia/reperfusion injury and correlation with tissue damage. Turk Neurosurg 19:353-359, 2009

33. Hugenholtz $H$, Cass DE, Dvorak MF, Fewer DH, Fox RJ, Izukawa DM, Lexchin J, Tuli S, Bharatwal N, Short C: Highdose methylprednisolone for acute closed spinal cord injury: Only a treatment option. Can J Neurol Sci 29(3):227-235, 2002

34. Ildan F, Polat S, Oner A, Isbir T, Gocer Al, Tap O, Kaya M, Karadayi A: Effects of naloxone on sodium and potassiumactivated and magnesium-dependent adenosine-5'-triphosphatase activity and lipid peroxidation and early ultrastructural findings after experimental spinal cord injury. Neurosurgery 36:797-805, 1995

35. Iplikçioglu C: Omurilik yaralanmasının fizyopatolojisi. In: Zileli M, Özer AF (ed), Omurilik Omurga Cerrahisi, ikinci baskı. İzmir: Saray Medikal Yayıncılık, 2002:459-465 (In Turkish)

36. Ji B, Li M, Budel S, Pepinsky RB, Walus L, Engber TM, Strittmatter SM, Relton JK: Effect of combined treatment with methylprednisolone and soluble Nogo-66 receptor after rat spinal cord injury. Eur J Neurosci 22(3):587-594, 2005

37. Kaptanoglu E, Beskonakli E, Solaroglu I, Kilinc A, Taskin Y: Magnesium sulfate treatment in experimental spinal cord injury: Emphasis on vascular changes and early clinical results. Neurosurg Rev 26: 283-287, 2003

38. Kaptanoglu E, Caner HH, Surucu HS, Akbiyik F: Effect of mexiletine on lipid peroxidation and early ultrastructural findings in experimental spinal cord injury. J Neurosurg 91 Suppl :200-204, 1999

39. Kaptanoglu E, Solaroglu I, Okutan O, Surucu HS, Akbiyik F, Beskonakli E: Erythropoietin exerts neuroprotection after acute spinal cord injury in rats: Effect on lipid peroxidation and early ultrastructural findings. Neurosurg Rev 27:113-120, 2004

40. Kaptanoglu E, Tuncel M, Palaoglu S, Konan A, Demirpence $\mathrm{E}$, Kilinc K: Comparison of the effects of melatonin and methylprednisolone in experi mental spinal cord injury. J Neurosurg 93 Suppl:77-84, 2000

41. Kaynar MY, Hanci M, Kafadar A, Gümüştaş K, Belce A, Ciplak $\mathrm{N}$ : The effect of duration of compression on lipid peroxidation after experimental spinal cord injury. Neurosurg Rev 21(23):117-120, 1998

42. Keystone EC, Kavanaugh AF, Sharp JT, Tannenbaum H, Hua Y, Teoh LS, Fischkoff SA, Chartash EK: Radiographic, clinical, and functional outcomes of treatment with adalimumab (a human anti-tumor necrosis factor monoclonal antibody) in patients with active rheumatoid arthritis receiving concomitant methotrexate therapy: A randomized, placebo-controlled, 52week trial. Arthritis Rheum 50(5):1400-1411, 2004

43. Keystone EC, van der Heijde D, Kavanaugh A, Kupper $H$, Liu S, Guérette B, Mozaffarian N: Clinical, functional, and radiographic benefits of longterm adalimumab plus methotrexate: Final 10-year data in longstanding rheumatoid arthritis. J Rheumatol 40(9):1487-1497, 2013
44. Kieseier BC, Kiefer R, Gold R, Hemmer B, Willison HJ, Hartung HP: Advances in understanding and treatment of immunemediated disorders of the peripheral nervous system. Muscle Nerve 30:131-156, 2004

45. Kim KT, Kim MJ, Cho DC, Park SH, Hwang JH, Sung JK, Cho HJ, Jeon Y: The neuroprotective effect of treatment with curcumin in acute spinal cord injury: Laboratory investigation. Neurol Med Chir (Tokyo) 54(5):387-394, 2014

46. Kokoszka JE, Coșkun P, Esposito LA, Wallace DC: Increased mitochondrial oxidative stress in the sod2 (+/-) mouse results in the age-related decline of mitochondrial function culminating in increased apoptosis. Proc Natl Acad Sci U.S.A 98:2278-2283, 2001

47. Kurt G, Ergün E, Cemil B, Borcek AO, Borcek P, Gülbahar O, Ceviker N: Neuroprotective effects of infliximab in experimental spinal cord injury. Surg Neurol 71:332-336, 2009

48. Kurt G, Yildirim Z, Cemil B, Celtikci E, Kaplanoglu GT: Effects of curcumin on acute spinal cord ischemia-reperfusion injury in rabbits. Laboratory investigation. J Neurosurg Spine 20(4):464-470, 2014

49. Kurtoglu T, Basoglu H, Ozkisacik EA, Cetin NK, Tataroglu C, Yenisey C, Discigil B: Effects of cilostazol on oxidative stress, systemic cytokine release, and spinal cord injury in a rat model of transient aortic occlusion. Ann Vasc Surg 28:479-488, 2014

50. Lammertse DP: Update on pharmaceutical trials in acute spinal cord injury. J Spinal Cord Med 27(4):319-325, 2004

51. Makol A, Grover M: Adalimumab induced mononeuritis multiplex in a patient with refractory rheumatoid arthritis: $A$ case report. Cases J 1(1):287,2008

52. Merola A, O'Brian MF, Castro BA, Smith DA, Eule JM, Lowe TG, Dwyer AP, Haher TR, Espat NJ: Histologic characterization of acute spinal cord injury treated with intravenous methylprednisolone. Orthop Trauma 16:155-161, 2002

53. Misawa S, Kuwabara S, Mori M, Kawagushi N, Yoshiyama Y, Hattori T: Serum levels of tumor necrosis factor-a in chronic inflammatory polyneuropathy. Neurology 56:666-669, 2001

54. Mohan N, Edwards ET, Cupps TR, Oliverio PJ, Sandberg G, Crayton $\mathrm{H}$, Richert JR, Siegel JN: Demyelination occurring during anti-tumor necrosis factor alpha therapy for inflammatory arthritides. Arthritis Rheum 44(12):2862-2869, 2001

55. Nielsen F, Mikkelsen BB, Nielsen JB, Andersen HR, Grandjean P: Plasma malondialdehyde as biomarker for oxidative stress: Reference interval and effects of life-style factors. Clin Chem 43: 1209-1214, 1997

56. Noble LJ, Wrathall JR: Spinal cord contusion in the rat: Morphometric analyses of alterations in the spinal cord. Exp Neurol 88(1):135-149, 1985

57. Noyes DH: Electromechanical impactor for producing experimental spinal cord injury in animals. Med Biol Eng Comput 25(3):335-340, 1987

58. Redford EJ, Hall SM, Smith KJ: Vascular changes and demyelination induced by the intraneural injection of tumor necrosis factor. Brain 118: 869-878, 1995

59. Reenaers C, Louis E, Belaiche J: Current directions of biologic therapies in inflammatory bowel disease. Therap Adv Gastroenterol 3(2):99-106, 2010

60. Rivlin AS, Tator $\mathrm{CH}$ : Effect of duration of acute spinal cord compression in a new acute cord injury model in the rat. Surg 
Neurol 10(1):38-43, 1978

61. Rivlin AS, Tator $\mathrm{CH}$ : Objective clinical assessment of motor function after experimental spinal cord injury in the rat. $J$ Neurosurg 47(4):577-581, 1977

62. Sayer FT, Kronvall E, Nilsson OG: Methylprednisolone treatment in acute spinal cord injury: The myth challenged through a structured analysis of published literature. Spine $J$ 6:335-343, 2006

63. Scheinfeld N: Adalimumab: A review of side effects. Expert Opin Drug Saf 4(4):637-641, 2005

64. Schmidley JW: Free radicals in central nervous system ischemia. Stroke 21(7):1086-1090, 1990

65. Shah SB, Hanauer SB: Risks and benefits of the use of concomitant immunosuppressives and biologics in inflammatory bowel disease. Rev Gastroenterol Disord 8(3):159-168, 2008

66. Sharief MK, Ciardi M, Thompson EJ: Blood-brain barrier damage in patients with bacterial meningitis: Association with tumor necrosis factor-alpha but not interleukin-1beta. $\mathrm{J}$ Infect Dis 166: 350-358, 1992

67. Sharief MK, McLean B, Thompson EJ: Elevated serum levels of tumor necrosis factor-a in Guillain-Barre syndrome. Ann Neurol 33:591-596, 1993

68. Smith PD, Puskas F, Meng X, Lee JH, Cleveland JC Jr, Weyant MJ, Fullerton DA, Reece TB: The evolution of chemokine release supports a bimodal mechanism of spinal cord ischemia and reperfusion injury. Circulation 126:S110-117, 2012

69. Taoka Y, Okajima K: Spinal cord injury in the rat. Prog Neurobiol 56: 341-358, 1998

70. Taoka J, Okajima K, Uchiba M, Johno M: Methylprednisolone reduces spinal cord injury in rats without affecting tumor necrosis factor-alpha production. J Neurotrauma 18: 533543, 2001

71. Taoka Y, Okajima K, Uchiba M, Murakami K, Harada N, Johno $M$, Naruo M: Activated protein $C$ reduces the severity of compression- induced spinal cord injury in rats by inhibiting activation of leukocytes. J Neurosci 18(4):1393-1398, 1998

72. Tator $\mathrm{CH}$ : Fehlings MG: Review of the secondary injury theory of acute spinal cord trauma with emphasis on vascular mechanisms. J Neurosurg 75:15-26, 1991

73. Topsakal C, Kilic N, Ozveren F, Akdemir I, Kaplan M, Tiftikci M: Effects of prostaglandin E1, melatonin, and oxytetracycline on lipid peroxidation, antioxidant defense system, paraoxonase (PON1) activities, and homocysteine levels in an animal model of spinal cord injury. Spine 28(15):1643-1652, 2003

74. Tsang RS, Valdivieso-Garcia A: Pathogenesis of Guillain-Barre syndrome. Expert Rev Anti Infect Ther 1: 597-608, 2003

75. Tufan K, Oztanir N, Ofluoglu E, Ozogul C, Uzum N,Dursun A, Pasaoglu H, Pasaoglu A: Ultrastructure protection and attenuation of lipid peroxidation a ter blockade of presynaptic release of glutamate by lamotrigine in experimental spinal cord injury. Neurosurg Focus 25:E6, 2008

76. Usul H, Arslan E, Cansever T, Cobanoglu U, Baykal S: Effects of clotrimazole on experimental spinal cord ischemia/ reperfusion injury in rats. Spine 33: 2863-2867, 2008

77. Wang CX, Nuttin B, Heremans H, Dom R, Gybels J: Production of tumor necrosis factor in spinal cord following traumatic injury in rats. J Neuroimmunol 69(1-2):151-156, 1996

78. Wang CX, Olschowka JA, Wrathall JR: Increase of interleukin-1 beta mRNA and protein in the spinal cord following experimental traumatic injury in the rat. Brain Res 759(2):190196, 1997

79. Yakovlev AG, Faden Al: Sequential expression of c-fos protooncogene, TNF-alpha, and dynorphin genes in spinal cord following experimental traumatic injury. Mol Chem Neuropathol 23(2-3):179-190, 1994

80. Yaman O, Yaman B, Aydın F, Var A, Temiz C: Hyperbaric oxygen treatment in the experimental spinal cord injury model. Spine J 14(9):2184-2194,2014

81. Yu Y, Matsuyama Y, Yanase M, Ito S, Adachi K, Satake K, Ishiguro N, Kiuchi K: Effects of hyperbaric oxygen on GDNF expression and apoptosis in spinal cord injury. Neuroreport 15: 2369-2373, 2004

82. Yuji T, Kenji O: Role of neutrophils in spinal cord injury in the rat. Neuroscience 79: 1177-1182, 1997

83. Zileli M: Omurilik yaralanmasında farmakolojik tedavi. In: Zileli M, Özer F (ed). Omurilik ve Omurga Cerrahisi. İzmir: Saray Yayıncllı, 1997:466-478 (In Turkish) 